\title{
Futsal as a strategy for the improvement of elementary abilities and for the development of the body image in children
}

\author{
Amanda A. Machado ${ }^{1 *}$, Ingrid S. Bezerra ${ }^{*}$, Katia Ponciano ${ }^{1 *}$, Roberta L. Rica ${ }^{1}$, Eliane F. \\ Gama $^{1}$, Aylton Figueira Junior ${ }^{1}$, Roberto Gimenez ${ }^{2}$, Danilo Sales Bocalini ${ }^{3}$ \\ ARTIGO ORIGINAL | ORIGINALARTICLE
}

\begin{abstract}
This current study aims to analyze the contribution of futsal practice in global praxis and body image in children in a specialized motor stage, evaluating the motor performance before and after an intervention in the following factors: hands and feet global praxis and body image. It was adopted the application method of 18 one-hour twice a week session, divided into three modules, I) displacement activities in different directions; II) coordination activities and reaction time and III) throwing and kicking activities. Twenty male participants, aged 8 to 12 years, with normal motor development were used. The survey was conducted at a private school. The results found were a significant improvement in the hits of the tennis balls with hands and make the number of hits in kicking the ball with his feet. Regarding the analysis of body image after the proposed intervention, the children has shown the body parts performance incorporated in drawings that were not previously present. It is concluded that there are positive contributions of the futsal practice in respect to the global praxis practice and body image in children in a specialized motor stage.

Keywords: body image and motor development.
\end{abstract}

\section{INTRODUCTION}

Medina-Papst and Marques (2010) summon that the motor experience by coordination, balance and body scheme amplify the motor development. The motor educational practices improve tone and balance, laterality and spacetime, and knowledge of the body itself, improving fine praxis and global praxis (Nicola, 2004; Gallahue, Ozmun, \& Goodway, 2013).

A diversified environment of motor activities may help children to create new situations and lead them to solve others by themselves. The movement is in constantly changing and improving, so it is important the environment exploitation and the choice of the motor activities. An organized and suitable place can enable the refining of children's motor vocabulary (Medina-Papst \& Marques, 2010). Thus, physical education classes can increase the children's motricity, developing their potential (Aquino, Browne, Sales, \& Dantas, 2012).
The child's motor development joins physical education and psychomotricity, since both focus on working the body in motion, promoting motor, cognitive and social affective gains (Aquino et al., 2012). Physical Education can be an indispensable basis that contributes with playful activities and gains in the corporal consciousness (Molinari \& Sens, 2003).

The development of body image features by the recognition of the self by the individual and occurs from some stages.

Stage I) early psychic experiences of the body, correspond to the first months of the baby's life, affections, movements and sensations, frequently shaped from the relationship with the mother.

Stage II) early awareness of the body image integrated with internal and external experiences, the several perceptions of their bodily parts are experienced by the child, at once belonging to themselves. In this stage, the ability to imagine is limited and primitive, as well as a thumb to suck instead of of the mother's womb or a blanket

Manuscript received at July 15 ${ }^{\text {th }} 2017$; Accepted at December $11^{\text {th }} 2017$

\footnotetext{
${ }^{1}$ Programa de Pós-graduação em Educação Física, Universidade São Judas Tadeu, São Paulo, SP, Brazil

${ }^{2}$ Programa de Pós-graduação em Educação, Universidade Cidade de São Paulo, São Paulo, SP, Brazil

${ }^{3}$ Laboratório de Fisiologia e Bioquímica Experimental. Universidade Federal do Espírito Santo, Vitoria, ES, Brazil

* These authors contributed equally on research and deserve the merit of first author: Oratorio Avenue 2635. Sao Lucas

Park. Sao Paulo. E-mail: kcapristi@gmail.com
} 
rather than the mother's skin. Through the development of the ability to imagine, the child can discriminate between the body that touches it and the object that is touched.

Stage III) is considered the definition and cohesion of the body-self as the basis of the ego-consciousness, it leads to develop the consciousness of a space beyond its body, being able to recognize itself in the mirror, recognizing in the mirror images created by its actions, where consolidation takes place of the sense of identity established from a cohesive and whole mental representation of the body (Amann-Gainotti \& Pallini, 2006). Therefore, at the child's aware of his body, he feels better and further the knowledge of his own corporal scheme, when the child is able to use it to reach a greater cognitive power (Aquino et al., 2012).

Taking into account that the Physical Education as an essential school subject for motor development, Santos (2015) summons that sports practices have contributed significantly to the motor development studies. Generally speaking, the systematized sports practices contribute to enlarge children's motor vocabulary.

Football, for instance, is a systematizing and dynamic sport practice, due to the diversity of actions during its practice. The contribution of football to motor activities can make the child learn to take up spaces, attack and defend, be aware with rules, etc. (Garganta, 1994). In Brazil the football is considered a social phenomenon, influencing the majority of classes and it has played an important role in the relationship with the media, besides the ease of implementation and the several possibilities of practice (Guterman, 2009).

The popularity of futsal and its practice has been increasing more and more among young people and children, revealing a great diversity of methods aimed at their learning (Voser \& Giust, 2002). Nonetheless, there are debates about the different teaching methodologies for the motor skills involved (Correia, Silva, \& Paroli, 2004). On the other hand, Silva and Greco (2009) mentioned the need to revisit the guided methods to the training and the learning process. Voser (2001) emphasizes the need to highlight the essential motor skills for soccer modality, which are influenced by the components: balance, rhythm, general coordination and space-time coordination.

It is known in the literature that the essential motor skills in football and its basic components improve considerably with the process of global motor development (Voser, 2001; Voser \& Giusti, 2002). Garganta (1994) supports the method of games to increase the overall children's development, whereas it allows the disassembly of the game in functional units and is reconstructed throughout the teachinglearning process.

Otherwise, the production of knowledge about the effective impacts of futsal practice on children's motor development is inconclusive (Isayama \& Gallardo, 1998; Stabelini Neto, Mascarenhas, \& Nunes, 2004). Among the existing works, doubts are raised about the the practical activities nature and the time in which the children are submitted to the practice (Ford, Williams, \& Hodges, 2005; Fonseca, Beltrame, \& Takac, 2008).

Thus, the present study aimed to analyse the contributions of futsal practice through conditioned games, in global praxis and body image in children in the specialized motor stage.

\section{METHOD}

\section{Participants}

A total of 20 male students, ranging from eight to twelve years old, with normal motor development according Saccani and Valentini (2010), took part in this study, regularly enrolled in a private school. This study was approved by the Research Ethics Committee of São Judas Tadeu University ( $\left.\mathrm{n}^{\circ} \quad 2.044 .114 / 2017\right)$. Previously to the data collection, it was sent to the parents or guardians a consent form, with the description of the objectives and the studies procedures, in order to allow the children's involvement. This is a nearly experimental study and makes evident as cross-study in the descriptive field (Thomas, Nelson, \& Silverman, 2007). 


\section{Procedures and Tasks}

It was applied eighteen one-hour twice a week session. The sessions were divided into three modules with their own characteristics, according the conditioned games described by Garganta (1994). They were:

- Module I: Displacement Activities in different directions and rhythms.

- Module II: Activities involving coordination and reaction time.

- $\quad$ Module III: Throwing and kicking activities.
The sessions were accomplished with a 10minute warm-up, a 25-minute playful time, a 20minute specific activity (Activities are represented in Figure 1: A to E) and a 5-minute slowdown. In the first module, the activities were accomplished in order to boost the children's movement confidence; in the second module some hints were used for learning improvement; and in the last module it was provided some hints and also it was introduced some futsal specific activities.

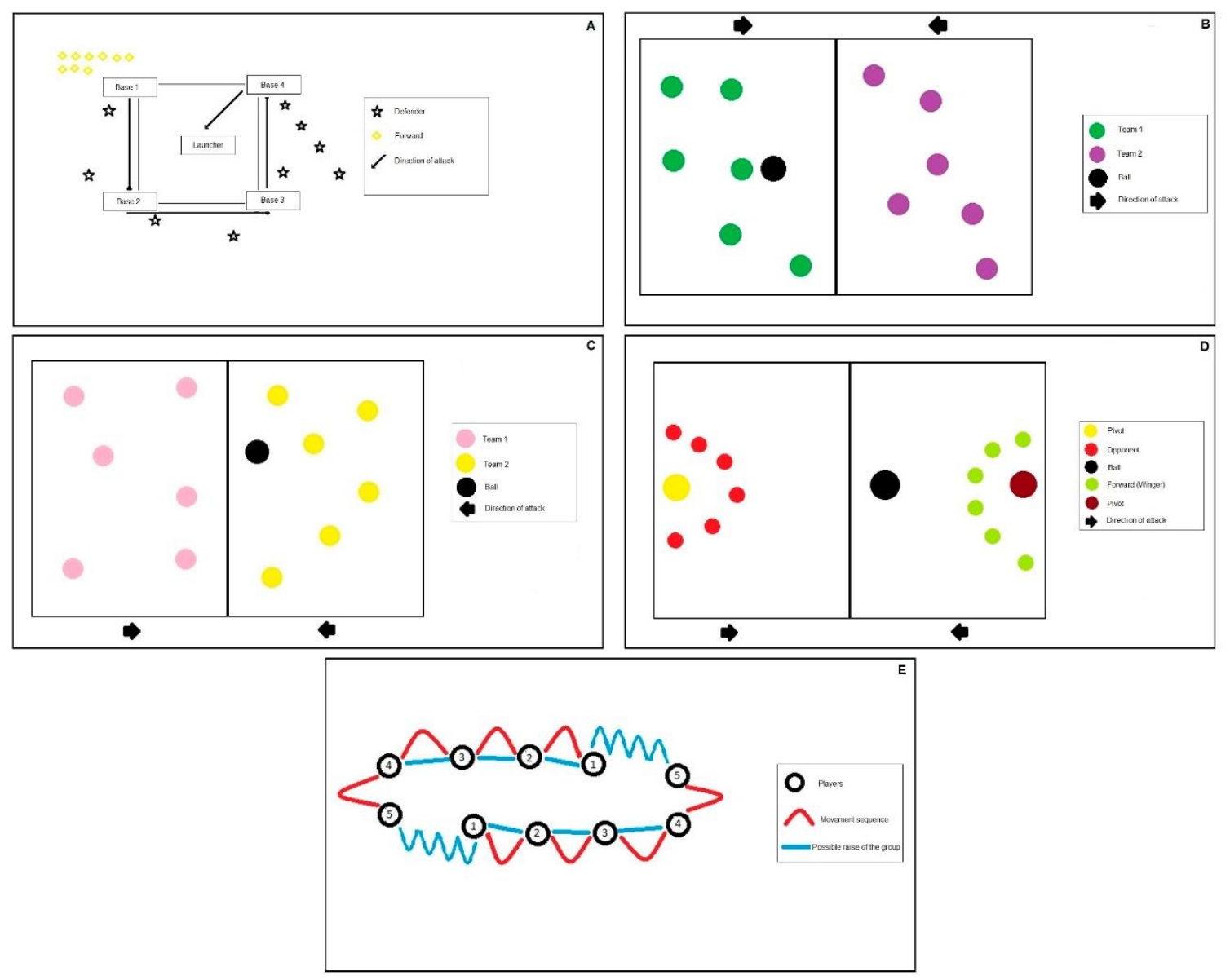

Figure 1. Development Activities A to E.

The team that endured in the defence spread around the futsal field in order to catch the ball rebound and hiding the attack from scores. The strike's team players, one at a time, were placed themselves in the first base so that they launched the ball as far as possible. Since the launch was done, the same one ran towards the second base. At the same time the defenders tried to catch the ball and pass it to the teammate who was near to the base. The latter, holding the ball, placed it on the ground to prevent the attacker from progressing. The launcher, while running, progressed as many bases as he could reached. Once feeling threatened, he stopped at one base and waited for the next pitcher. One score was computed when a striker walked all three bases. The task did not allow two players on the same base. Thus, the one who had first entered, obligatory, would have to change base, if he would not, he would be leave out. This player 
should go out and return to the same base. After all the players of the team went though the position of striker, they also went through the position of launcher, changing the positions in which who attacked received and vice versa (Figure A- Base four).

The field was bounded by a line, which divided it into two sides. Thus, each team took possession of one side of the bounded space. The players stood on the edge of their suitable field. The match started with of the teams' ball possession. One player launched, trying to hit someone from the opposing team, if the ball hit a player and felt to the ground, the player would be considered "burned" and also "dead." But if he managed to hold the ball or hit it in his head, he would be considered "alive." When burned, the player had to go behind the bottom line of the opposing field and throw the ball in order to burn someone from the opposing team or just return it to their field. The game was ended when all the members of a team were burned (Figure 1 BBurned with the hands).

The players were divided into two equal groups, parted by the middle line. One of the teams started the match kicking the ball to burn one of the opponents. They could flee the ball as long as they did not leave the bounded area. The goal of the game was to burn as many opposing players as possible until there were none left, and it was not possible to score with head hits. The burned player had to go behind the line that marks the final boundary of the opponent's court - called a "prison" or "graveyard." From this place he should throw the ball from there to his own team. The team that could burn all players or burn as much as possible, within the previously agreed term, was the winner. It is important to remember that to burn it was not possible to use the hands but the feet (Figure C - Burned with the feet).

The game consisted of two teams where each one occupied one side of the space divided by the centre line. The teams had the same number of members and were responsible for choosing a person to be the "pin" of the team. After choosing the "pin" of each team, the same was set space and his teammates were around (keeping some distance), the team that was in possession of the ball tried to hit the "pin" opponent and his teammates had to defend. The purpose of the activity was to hit the "pin" (Figure D - Pin).

Participants were divided into two groups, compound two columns on opposite sides, and there were four (4) participants in a straight line at a given distance. The activity started with two balls, where each participant who was in position number 1 passed the ball to the Participant number 2 and thus successively until reaching the participant number 4 that passed to the participant number 5 of the other column (Figure E - Pass lightly).

In module 1, the ball passed was through the pitch, in the second module the practice was performed with the same distribution of the participants in the space, however the possession of the ball was changed. In this case, participant number 1 would throw the ball to the participant number 2's foot, who made the reception with the foot and then it would pass for the next participant. The latter received with the hands and then threw to the participant number 4 . And in the last module passes and receptions were made with the feet.

\section{Praxia Psychomotor and Task Test}

\section{Oculo-manual and oculo-motor coordination}

In order to verify the level of global praxis, two psychomotor test were used before and after the conditioned games according to Fonseca (1995).

Oculo-manual coordination: The standing child throws a tennis ball with his hands to a basket placed on top of a chair, at a distance of $2.50 \mathrm{~m}$. The first attempt was to become confident and after that, four more throws were done. Based on the accomplishment of this task, It was imputed the following scores criteria:

1 point: When the child did not succeed in any attempt, would bring out dyspnea, dyskinesias, dyskinesias, obvious discontinuities, besides synkinesis, rebalancing, hesitation of dominance, temporal-space disorientation, choreoateoid movements.

2 points: When the child hit one of the four attempts, would bring out dyspraxias, dystonias, dyskinesias and discronias. 
3 points: When the child hit two of the four attempts, would bring out suitable motor planning and visuomotor control, with signs of dysfunctional indiscernible.

4 points: When the child hit four or three of the four attempts, would bring out perfect motor planning and accurate self-control with kinetic melody and eumetry.

\section{Eye-Pedal coordination}

The standing child was encouraged to accomplish a kicking test with a tennis ball aiming to make the ball pass between the legs of a chair, at a distance of $2.50 \mathrm{~m}$. After the first attempt, four kicks were taken in sequence. It was scored as follows:

1 point: 1 If the child did not hit any kick, would bring out dyspnea, dyskinesias, dyskinesias, obvious discronias, in addition to psychokinesis, rebalancing, hesitation of dominance, spatio-temporal disorientation, choreoatetoid movements, etc.

2 points: If the child hit one in four kicks, would bring outdyspnea, dyskinesias, dyskinesias, and dyschondrias.

3 points: If the child hits two in four kicks, would bring out appropriate motor planning and visual motor control, with indiscernible dysfunctional signs.

4 points: If the child hits three or four in four kicks, would bring out perfect motor planning and accurate self-control with kinetic melody and eumetry.

\section{Motor performance}

Motor performance was analysed by an observation protocol as described by Fonseca (1995). The motor skill performance at passing, kicking, domain and driving were evaluated according to following criteria:

1 point: imperfect performance, incomplete and disorderly, weak;
2 points: performance with difficulties in controlling, satisfying;

3 points: controlled and adequate performance; good;

4 points: perfect performance, saving, harmonious and well controlled, excellent.

\section{Body image}

Since the children were encouraged to draw their own body using only graphite pencil, coloured pencil and bond paper sheet, the drawings were analysed using the Wintsch scale as described by Fonseca (1988). This scale analysis was done before and after the conditioned games.

\section{Statistical analyses}

For the statistics analysis it was used in only only sample: average, mean deviation, the Kolmogorov-Smirnov test and interaction test. Aiming the frequency comparison, it was used the Chi-Squared. All the tests were performed using of the Prisma 4.0 software (GraphPad Softwares Inc., San Diego, CA, USA) with a significance level of $\mathrm{p}<0.05$.

\section{RESULTS}

The Figure 2 illustrates the results regarding the children's performance. A significant improvement of $40 \%(p=0.0001)$ was found in the successful throwing of the tennis ball with the hands (Fig. 2A). In a similar way, a significant improvement of $45 \%(p=0.0001)$ was observed in the number of hits performed by the children in kicking the ball with their feet (Fig. 2B).

When analysing the overall children's praxia during the tests in Figure 3, there was a significant reduction of $38 \%(p=0.0001)$ for the ball throwing with hands (Fig. $3 \mathrm{~A}$ ) and $45 \%$ ( $\mathrm{p}=$ 0.0001) during kicking (Fig. 3B). 
A

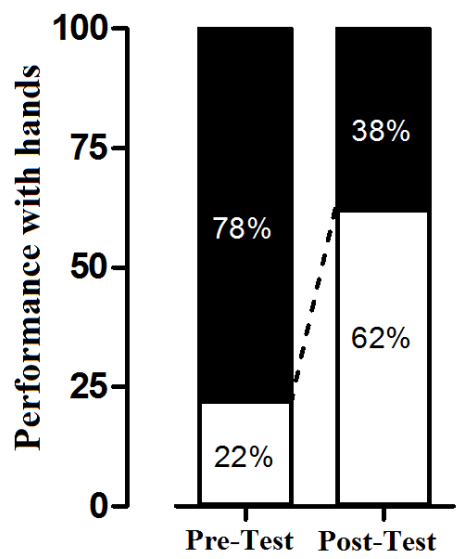

B

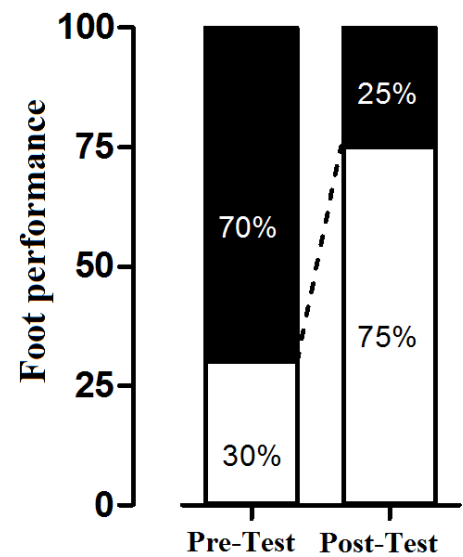

Figure 2. Correct categorization ) or error

of children's performance in throwing with hands (Figure $2 \mathrm{~A})$ and kicking (Figure 2B) the tennis ball evaluated before and after the experimental phase $\left(\mathrm{p}=0.0001, \chi^{2}\right.$ test).

A

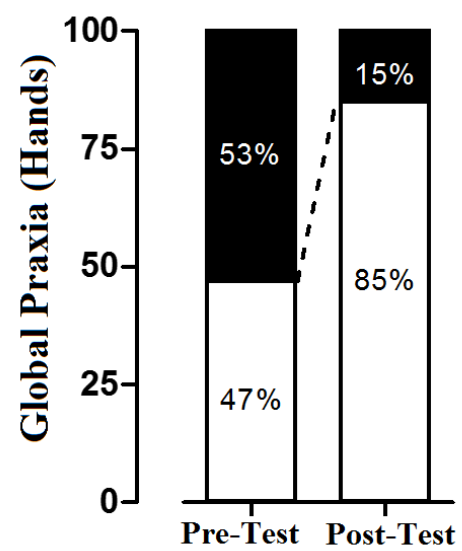

B

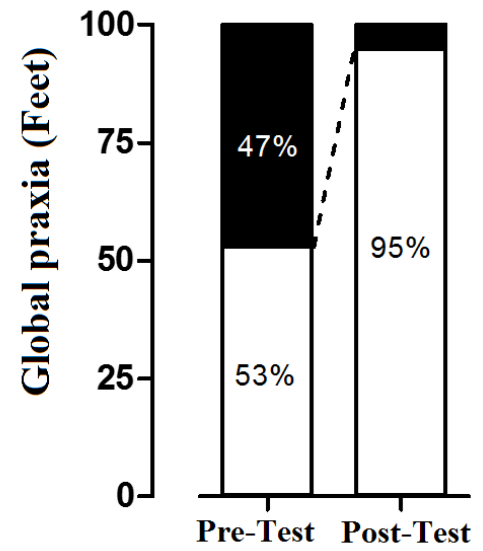

Figure 3. Categorization by praxia absence $(\square)$ or presence

during the throwing test (Figure $3 \mathrm{~A}$ ) and kick (Figure $3 \mathrm{~B}$ ) the tennis ball evaluated before and after the experimental phase $\left(\mathrm{p}=0.0001, \chi^{2}\right.$ test).

\section{Table 1}

Description of the body parts before and after the interventions through the classes.

\begin{tabular}{lccccc}
\hline & \multicolumn{2}{c}{ Pre-test } & \multicolumn{2}{c}{ Post-test } & \multirow{2}{*}{ Meaningfulness } \\
\cline { 2 - 5 } & Yes & No & Yes & No & \\
\hline Eyebrow & $13 \%$ & $87 \%$ & $65 \%$ & $35 \%$ & 0.007 \\
Nose & $87 \%$ & $13 \%$ & $100 \%$ & ---- & 0.482 \\
Ear & $57 \%$ & $43 \%$ & $97 \%$ & $3 \%$ & 0.035 \\
Neck & $80 \%$ & $20 \%$ & $98 \%$ & $2 \%$ & 0.224 \\
Fingers & $76 \%$ & $24 \%$ & $97 \%$ & $3 \%$ & 0.042 \\
\hline
\end{tabular}

Values expressed as a percentage and the Chi-squared test was used to compare frequency of appearance.

When the self-image from all children was analysed, before and after the sessions, they showed in their drawings the following body pairs: eye, mouth, torso, arm, hand, leg, foot and hair. Nevertheless, some body parts representations, which have been incorporated into the drawings, can be observed after the class sessions (Table 1).

\section{DISCUSSION}

The main findings of the present study are directed related to the improvement of global praxis and self-image by the technique of selfdescription of children in the specialized motor stage after 12 weeks of futsal practice. In respect to the protocol length of time, our study consisted of 18 one-hour sessions, performed twice a week, the same as used in some other studies (Campos, Silva, Pereira, Rocha, \& Tudella, 2008; Oliani \& Navarro 2009; Santos, 
2015; Venâncio, Teixeira Júnior, Teixeira, Silva, \& Camarço, 2010).

Our results were similar to Campos et al. (2008), which children after 16 one-hour sessions, twice a week of a psychomotor intervention program obtained significant results in psychomotor performance in the score of the factors tonicity, global praxis and fine praxis after elaboration. Oliani and Navarro (2009) found improvement in eye-pedal coordination when comparing 8 to 10 -year-old schoolchildren who practiced futsal twice a week, in addition to Physical Education classes in comparison to the group that performed only physical education classes. Neris, Tkac, and Braga (2012), evaluating the children's motor performance from 7 to 10 years old, who performed sports activities and only conventional physical education, showed strict influence in motor development, especially in manipulation tasks such as grabbing, kicking and throwing a ball in children who play sports.

Santos (2015), demonstrate that children who performing extracurricular sports activities showed improvements in tasks of global motor skills and body schema when compared to children who only did conventional physical education classes. Using futsal practice, Venâncio et al. (2010) proved that the practice of futsal improved motor skills, due to the opportunity to experience several movements and experiences that enabled the increase of the motor heritage. Alike, Santos (2015), analysing the influence of the programmed classic ballet and futsal sports on global motricity indicators in children aged 7 to 10 showed higher scores in the evaluation of global motricity compared to children belonging exclusively to School Physical Education.

Regarding the analysis of body image, the significant results of our study when evaluating the human figure with the items eye, mouth, torso, arm, hand, leg and foot reinforce motor encouragement importance for children. According to Martens, Wilson, and Reutens (2008), the body segments are essential items which represent the body. In addition to Melo (1994) as the child's background is stimulated, they start to better control the parts of the body and body knowledge is becoming wider, including new elements that were not previously represented in the drawing demonstrate the relationship between body image and identity.

Our study results suggest that the motor activities performed during futsal practice can significantly influence the relations of body perception and motor action. In addition, Neto (2001) considers that body awareness can also be improved through the other's body awareness, encouraged by tasks of socialization and cooperation through synesthetic activities, common practices in interventions with physical activities or classes of traditional physical education.

An important limitation which have be considered in this study corresponds to the gap of information about the activities that the children developed out of the school environment, as well as other spaces of physical activity practice, preventing any direct association with the activities developed in the present study. This limitation could be partially through an experimental design setting, involving a control group not submitted to the practice of the modality and respective activities of stimulation.

Although, it is worth mentioning that the modality presents the requirements that can increase the learning possibilities. This stimulus is converted into a nerve impulse by the sense organs, resulting in an information exchange with the environment (Romanelli, 2003). For this matter of performance changes, the valorisation of the neural processes is one of the most important aspects, since there are different neural circuits and fundamental mechanisms when there are different forms of learning (Azcoaga, 1972; Ciasca, 2003). This process requires a certain level of activation and attention, vigilance and selection of information, all these essential elements of neuropsychological activity. It is necessary a cerebral organization, intra and inter neurosensorial for learning, emphasizing that the processes of codification and decoding are important (Ciasca, 2003).

It is worth emphasizing that, with practice, these processes undergo changes, re-significances that are very influenced by the nature of the motor task practiced. In other words, the variations in the positions and conditions of play, typical of the futsal game and the activities carried 
out in conjunction with the developed program, may well contribute to the development of learning and the formation of neural maps or motor programs (Schmidt \& Wriberg, 2001).

\section{CONCLUSION}

The 12-week futsal practice contributed to improve global praxis and body image of school children, cooperating with the motor skill increase, as well as increasing their recognition of body segments. Other studies are necessary with different age groups and genders, in the different stages of learning and through different teaching methodologies. In addition, studies are needed, oriented to the new forms of intervention and sports modalities, with the purpose on contributing to a better motor development of typical school children of different levels of basic education.

\section{Acknowledgments:}

Nothing to declare

Conflict of interests:

Nothing to declare.

\section{Funding:}

Nothing to declare.

\section{REFERENCES}

Amann-Gainotti, M., \& Pallini, S. (2006). Spontaneous geographical maps of Europe by Italian school children. Cognition Process, 7(1), 112-114.

Aquino, M. F. S., Browne, R. A. V., Sales, M. M., \& Dantas, R. A. E. (2012). Psicomotricidade como ferramenta da educação física na educação infantil. Revista Brasileira de Futsal e Futebol, 4(14), 245-257.

Azcoaga, T. (1972). Sistema nervioso y aprendizaje. Buenos Aires: Cuadernos LatinoAmericanos de Educacion.

Campos, A. C., Silva, L. H., Pereira, K., Rocha, N. A. C. F., \& Tudella, E. (2008). Intervenção psicomotora em crianças de nível socioeconômico baixo. Revista Fisioterapia $e$ Pesquisa, 15(2), 188-93.

Carvalho, F. M., Scaglia, A. J., \& Costa, I. T. (2013). Influência do desempenho tático sobre o resultado final em jogo reduzido de futebol. Revista Educação Física - UEM, 24(3), 393-400.

Ciasca, S. M. (2003). Distúrbios e dificuldades de aprendizagem: questão de nomenclatura. In: S. M. Ciasca (Ed.) Distúrbios de aprendizagem: proposta de avaliação interdisciplinar. São Paulo: Casa do Psicólogo.

Correia, U. C., Silva, A. S., \& Paroli, R. (2004). Efeitos de diferentes métodos de ensino na aprendizagem do futebol de salão. MotrizRevista de Educação Física - UNESP, 10(2), 7988.

Fonseca, F. R., Beltrame, T. S., \& Takac, C. M. (2008). Relação entre o nível de desenvolvimento motor e variável do contexto de desenvolvimento de crianças. Revista de Educação Física da UEM, 19(2), 183194.

Fonseca, V. (1995). Manual de Observação psicomotora: Significaçãa psiconeurológica dos fatores psicomotores. Porto Alegre: Artes Médicas.

Fonseca, V. (1988). Psicomotricidade. (2a ed.). São Paulo: Martins Fontes.

Ford, P., Williams, A. M., \& Hodges, N. J. (2005). Online attentional-focus in soccer dribbling task: implications for the proceduralization of motor skills. Journal of Motor Behavior, 37(5), 386-394.

Gallahue, D. L., Ozmun, J. C., \& Goodway, J. D. (2013). Compreendendo o desenvolvimento motor. Bebes Crianças, Adolescentes e Adultos. (7a ed.). Porto Alegre: Editora McGraw-Hill - Artmed.

Garganta, J. (1994). Para uma teoria dos jogos desportivos colectivos. In: A. Graça \& J. Oliveira (orgs.). O ensino dos jogos desportivos. Centro de Estudos dos Jogos Desportivos. Portugal: FCDEF-UP.

Garganta, J. (2001). A análise da performance nos jogos desportivos. Revisão acerca da análise do jogo. Revista Portuguesa de Ciências do Desporto, 1(1), 57-64.

Guterman, M. (2009). O futebol explica o Brasil: uma história da maior expressão popular do país. São Paulo: Contexto.

Isayama, H. F., \& Gallardo, J. S. P. (1998). Desenvolvimento motor: análise de estudos brasileiros sobre habilidades motoras fundamentais. Revista de Educação Física da UEM, 9(1), 75-82.

Martens, M. A., Wilson, S. J., \& Reutens, D. C. (2008). Research Review: Williams syndrome: a critical review of the cognitive, behavioral and neuroanatomical phenotype. 
Journal of Child Psychology and Psychiatry, 49(6), 576-608.

Medina-Papst, J., \& Marques, I. (2010). Avaliação do desenvolvimento motor de crianças com dificuldades de aprendizagem. Revista Brasileira de Cineantropometria e Desempenho Humano, 12 (1), 36-42.

Melo, J. P. (1994). Desenvolvimento da consciência corporal: uma experiência da educação física na idade pré-escolar. Campinas: Editora da Unicamp.

Molinari, A. P., \& Sens. S. M. (2003). A Educação e sua Relação com a Psicomotricidade. Revista Psicologia Educação Cultura, 3(1), 8593.

Neris, K. C. F., Tkac, C. M., \& Braga, R. K. (2012). A influência das diferentes práticas esportivas no desenvolvimento motor em crianças. Revista Acta Brasileira do Movimento Humano, 2(1), 58-64.

Neto, C. A. F. (2001). Motricidade e jogo na infância. ( $3^{\text {a }}$ ed.). Rio de Janeiro: Sprint.

Nicola, M. (2004). Psicomotricidade: Manual Básico. Rio de Janeiro: Revinter.

Romanelli, E. J. (2003). Neuropsicologia aplicada aos distúrbios de aprendizagem: prevenção e terapia. Temas em Educação II - Jornadas.

Saccani, R., \& Valentini, N. C. (2010). Análise do desenvolvimento motor de crianças de zero a 18 meses de idade: representatividade dos ítens da alberta infant motor scale por faixa etária e postura. Revista Brasileira de Crescimento e Desenvolvimento Humano, 20(3), 711-722.

Oliani, F. F., \& Navarro, A. C. (2009). A influência do futsal na coordenação óculo- pedal em escolares de 8 a 10 anos. Revista Brasileira de Futsal e Futebol, 1(2), 97-102.

Silva, M. V., \& Greco, P. J. (2009). A influência dos métodos de ensino-aprendizagemtreinamento no desenvolvimento da inteligência e criatividade tática em atletas de futsal. Revista Brasileira de Educação Física e Esporte, 23(3), 297-307.

Santos, C. R. (2015). Efeito da atividade esportiva sistematizada sobre o desenvolvimento motor de crianças de sete a 10 anos. Revista Brasileira de Educação Física e Esporte, 29(3), 497-506.

Schmidt, R., \& Wrisberg, C. (2001). Aprendizagem e performance motora: uma abordagem orientada ao problema. Porto Alegre: Artmed.

Stabelini Neto, A., Mascarenhas, L. P. G., \& Nunes, G. F. (2004). Relação entre fatores ambientais e habilidades motoras básicas em crianças de 6 e 7 anos. Revista Mackenzie de Educação Física e Esporte, 3(3), 135-140.

Thomas, J. R., Nelson, J. K., \& Silverman, S. J. (2007). Metodologia da pesquisa em Educação Física. ( $5^{\mathrm{a}}$ ed.). São Paulo: Artmed.

Venâncio, P. E., Teixeira Jr, J., Teixeira, C. G., Silva, F. M., \& Camarço, N. (2010, setembro). Desenvolvimento motor com a prática do futsal em crianças de 08 a 11 anos de uma escola particular em Anápolis. Anais do IV congresso centro-oeste de ciências do esporte, Brasília, DF, Brasil.

Voser, R. C., \& Giusti, J. G. (2002). O futsal e a escola: uma perspectiva pedagógica. Porto Alegre: Artmed.

Voser, R. C. N (2001). Futsal: princípios técnicos e táticos. Rio de Janeiro: Sprint. 